\title{
Sistemas de produção de leite sobre cama de compostagem: características e potencialidades
}

Adriano Rudi Maixner, Cristiano Kraemer Didoné, José Carlos de Figueiredo Pantoja, Gilmar Roberto Meinerz, Ricardo Lopes Machado

https://doi.org/10.4322/mp.978-65-991393-1-4.c3

\section{Introdução}

"Qual é o melhor sistema de produção de leite?" Essa é uma pergunta frequente entre produtores frente às demandas de mercado e as opções tecnológicas que surgem. A resposta mais adequada, a princípio, é: "Depende!" Essa dependência está relacionada a múltiplos fatores relacionados às condições mercadológicas em que o sistema de produção está inserido, a capacidade de investimento na atividade leiteira, o domínio das técnicas de produção, o nível de controle gerencial e administrativo, entre vários outros. A realidade é que distintos sistemas de produção têm sido conduzidos com sucesso em todo o Rio Grande do Sul, demonstrando que o atendimento a estas condições específicas é que permite usufruir de sistemas de produção diversos com suficiente êxito. O tema Sistemas de Produção de Leite trouxe para discussão os elementos que caracterizam os principais sistemas de produção ocorrentes no estado: baseado em pastejo direto e com suplementação de alimentos concentrados; baseado em pastejo direto, com suplementação de alimentos concentrados e volumosos; e o sistema confinamento, com ênfase no sistema sobre cama de compostagem - "compost barn". Os registros escritos foram feitos pelos painelistas e optou-se por manter seus textos originais. Mais do que isto, a ampla discussão gerou contribuições escritas também extensas, demandando a separação dos temas para melhor apresentação. Neste capítulo, são apresentados os elementos de sistemas de produção de leite em cama de compostagem. Este registro não pretende esgotar qualquer tema, mas contribuir com informações importantes nessa área do conhecimento.

\section{Considerações práticas sobre adoção e manejo em confinamento de vacas leiteiras sobre cama em compostagem}

O evento contou com a participação de Cristiano Kraemer Didoné, produtor de leite no município de ljuí, Rio Grande do Sul, que relatou sua história na produção leiteira e experiência recente na adoção do sistema de produção em cama de compostagem ("compost barn").

A propriedade, de 25 hectares, passou a considerar a pecuária leiteira como principal atividade econômica a partir de 2005, com investimentos na formação de pastagens perenes, aquisição de animais, infraestrutura e equipamentos. O produtor também investiu na sua capacitação técnica, o que permitiu, em 2012, trabalhar com animais de genética apurada e com um rebanho de cerca de 35 animais em produção, sem consideráveis problemas produtivos/reprodutivos, e comercializando leite à preços levemente acima da média de mercado (remuneração por qualidade). Nessa época, a alimentação dos animais era realizada em pastejo direto em 4 hectares de tifton 85 
(irrigado), no verão, e 11 hectares de aveia preta + azevém, no inverno. Também no verão, 8 hectares de milho eram cultivados para a produção de silagem, fornecida durante todo o ano a fim de regular a estacionalidade de oferta de volumoso das pastagens. Concentrados eram fornecidos diariamente para a adequação nutricional.

A implantação do sistema confinado sobre cama de compostagem ocorreu em meados de 2015 , decorrente da expectativa de alcançar maior renda na propriedade, da necessidade de reduzir impactos ambientais gerados pela alta lotação animal (especialmente a ocorrência de barro) e de um cenário positivo em termos de parceria com outro produtor vizinho (Lauri Seifert).

Do novo modelo produtivo, surgiu a "Agropecuária Didoné e Seifert". Os rebanhos leiteiros das duas propriedades foram reunidos e, embora em sistema de sociedade, cada produtor passou a desempenhar etapas distintas do processo produtivo: um responsável pela recria das terneiras e condução das lavouras para a produção do volumoso; outro, pelo manejo dos animais adultos (secos ou em lactação).

Alguns aspectos chave da mudança de matriz tecnológica foram apresentados durante o evento, entre eles:

a) Investimento em infraestrutura a alto custo operacional.

No primeiro momento, a adoção do sistema ocorreu com o ajuste na infraestrutura em relação à condição já existente na propriedade. Investiu-se na construção do galpão, instalações para o manejo de dejetos e armazenamento dos alimentos (volumoso e concentrado) e na contratação de mão de obra. O galpão tem $2800 \mathrm{~m}^{2}$, com custo estimado em $\mathrm{R} \$ 3.200,00$ para cada um dos 160 animais em produção que podem ser estabulados. Foi possível utilizar, no primeiro momento, os maquinários para as operações de campo e estruturas e equipamentos para ordenha foram já existentes nas unidades de produção.

Com o aumento gradual do rebanho outros investimentos se fizeram necessários. Uma nova sala de ordenha foi adquirida, com capacidade de ordenha de 80 vacas por hora, assim como um novo tanque resfriador com maior capacidade de armazenamento. A implementação da terceira ordenha diária também tem sido avaliada como necessidade no novo modelo, mas há dificuldades em contratar mão de obra qualificada para esta finalidade.

Dois aspectos foram especialmente ressaltados pelo produtor: a necessidade de investimentos progressivos até que todas as vagas estabuladas estejam preenchidas; e o alto investimento (endividamento) por conta do capital imobilizado. Um investimento gera demanda de mais dois ou três outros e muitos deles ainda não foram pagos. Contudo, se não há investimento sequencial, não há o crescimento necessário e a viabilidade do negócio torna-se duvidosa. Nas avaliações do produtor, apenas uma produção diária de acima de 4.000 litros é que permitirá condições de cumprir com as dívidas e viabilizar o negócio. É um empreendimento grande, arriscado e em que, dado o pontapé inicial, não há retorno.

Toda a alimentação dos animais é provida por volumosos conservados (silagem) e concentrados, no cocho, com envolvimento de maiores custos de produção da alimentação e da mão de obra para o fornecimento em comparação com o sistema a pasto com suplementação volumosa. O custo estimado da dieta da vacas Holandês é de $\mathrm{R} \$ 16,50$ e, das Jersey, $\mathrm{R} \$ 11,26$, com produções médias de 29 e 20 litros/vaca/dia, respectivamente. Em novembro de 2016, a média final de produção estava entre 24 - 26 litros (hoje 24,6 litros/vaca/dia) e o custo por litro de leite era de 
$\mathrm{R} \$ 1,42$ (contando o pró-labore) e de $\mathrm{R} \$ 1,56$ (quando incluídos os valores de depreciação).

b) Aumento da dependência por insumos externos à propriedade.

Aumentou-se também a dependência por insumos externos à propriedade. Talvez o relato mais marcante tenha sido a carência de material na região para a reposição da cama (maravalha). De fato, notou-se a implantação de outros sistemas confinados sobre cama de compostagem na região e, mantendo-se a oferta de maravalha, houve falta do produto frente ao aumento da demanda. Outros materiais, pela maior disponibilidade regional, foram testados sem sucesso (palha de soja, por exemplo). Frente à importância do manejo da cama no sistema, a solução efetiva foi a compra de uma máquina de fazer maravalha e o arrendamento de uma área com Pinus para obtenção da matéria prima.

\section{c) Nova sistemática de manejo dos animais:}

O trabalho com maior número de animais gerou também desafios em termos de manejo geral do rebanho. Hoje, o rebanho em produção é de 55 vacas da raça Jersey e 65 vacas da raça Holandês, ou seja, ainda há capacidade ociosa. A área do galpão está dividida para lotes pós-parto, Holandês em lactação, Jersey em lactação e vacas secas (pré-parto), sendo áreas dimensionadas para receber um número fixo de animais em cada fase. Cada lote recebe uma dieta padrão (silagem + concentrado) em cada fase e o fator principal que determina o ritmo de ocupação das instalações é o desempenho reprodutivo. Especialmente em relação aos dois lotes em produção (com maior número de animais), o fornecimento da alimentação têm sido um desafio, pois os ajustes nutricionais (recomendados para cada fase de lactação) são de difícil execução prática. Mais que isso, há maior exigência em capacidade técnica e gerencial do negócio, obrigando o produtor a adotar um alto nível de controle do processo produtivo.

O rebanho vem aumentando gradualmente, com recria própria e a aquisição de animais externos à propriedade. Até o final de 2017, espera-se agrupar 140 animais em ordenha, com projeção de produção diária de 4.000 litros de leite.

Concluindo sua participação, Cristiano acredita que todos os sistemas de produção de leite são viáveis, desde que enquadrados dentro de certas peculiaridades, e que cada sistema de produção revela desafios distintos a serem vencidos. O sistema de produção sobre cama de compostagem aposta na escala produtiva para a geração da renda pretendida, mas torna-se dependente de inúmeros fatores internos (refinados controles técnico e econômico e imobilização de capital - especialmente em infraestrutura) e externos (disponibilidade e preço de insumos e preço do produto comercial). Além disso, são determinantes do sucesso neste sistema o domínio das práticas técnicas, ajustando com frequência todos os fatores produtivos, e a garantia de preços estáveis ao produtor, que trabalha com maiores custos.

\section{O uso da cama em compostagem para o confinamento de vacas leiteiras}

O alojamento de vacas livres em camas manejadas pelo sistema de compostagem ("compost barn") tem crescido rapidamente ao redor do mundo e, principalmente, no Brasil. Pesquisas realizadas na América do Norte indicaram que as principais razões para a adoção do sistema foram o conforto dos animais, aumento da longevidade (diminuição de problemas de casco e lesões em geral), facilidade em completar tarefas diárias de manejo e menor custo de implantação quando comparado aos freestalls tradicionais. Uma das principais motivações para a implantação seria 
também a redução drástica na quantidade de dejetos animais eliminados no meio ambiente, o que poderia contribuir substancialmente para a sustentabilidade da pecuária leiteira.

No Brasil, embora ainda não haja dados científicos publicados, relatos de produtores e consultores indicam que uma das principais justificativas para a adoção do sistema é a transição de sistemas caracterizados por más condições de higiene e conforto animal, tais como o semi-confinamento, para o confinamento integral no "compost barn". Dessa forma, o sistema de compostagem seria uma alternativa de menor custo do que o confinamento de animais em freestalls tradicionais, e que ainda propiciaria um ambiente adequado para a expressão do potencial genético-produtivo dos animais.

O sistema de compostagem é iniciado com uma camada de cerca de $40 \mathrm{~cm}$ de uma base orgânica como serragem ou maravalha espalhada em um galpão coberto com piso de terra compactada. A qualidade da cama é determinada por uma variedade de fatores, tais como o tamanho e tipo das partículas, lotação, umidade, aeração, temperatura, densidade (compactação) e relação carbono:nitrogênio. A lotação recomendada é de 10 a $20 \mathrm{~m}^{2} /$ vaca e é importante notar que o aumento da densidade animal resultará em maiores dificuldades de manejo, devido a maior compactação e influxo de fezes e urina. Uma vez que as vacas comecem a defecar e urinar sobre a cama, a atividade dos micro-organismos (principalmente bactérias) fermenta o material e produz calor, o que provoca um aquecimento da camada profunda da cama. Temperaturas entre 40 e $60^{\circ} \mathrm{C}$ são observadas a $20 \mathrm{~cm}$ de profundidade.

A cama deve ser aerada com subsoladores e/ou enxadas rotativas duas vezes ao dia, durante o intervalo entre ordenhas, para que ocorra a incorporação dos dejetos animais e descompactação do material. A presença de ar é fundamental para a eficiência do processo. É importante não aplicar o subsolador de forma muito profunda, pois isso poderá trazer terra para a camada de cama e contribuir para a compactação da mesma. Da mesma forma, aerar somente a camada superficial (por exemplo, por meio do uso exclusivo da enxada rotativa) pode resultar em apodrecimento da camada profunda e perda de todo o material. A enxada rotativa é importante para a descompactação da cama porque quebra os torrões formados, deixando-a solta e aerada. Cama nova deve ser adicionada à cama existente em intervalos de uma a oito semanas, para controle da umidade e adição de substrato para os microrganismos. É importante adicionar o novo material com o mínimo possível de umidade.

A umidade da cama é importante para a decomposição microbiana da cama, mas níveis excessivos (geralmente $>50 \%$ ) resultam em compactação do material. A compactação, por sua vez, resulta na diminuição da penetração de ar e consequente degradação anaeróbica do material, o que pode levar ao "apodrecimento" e esfriamento da cama, aumento na concentração de bactérias e maior aderência à pele dos animais, resultando em aumento da ocorrência de mastite ambiental. Este tipo de situação ocorre mais frequentemente quando produtores estão aprendendo a manejar o sistema e pode ser melhorada pelo uso de práticas de manejo que visem retornar a cama a um estado de baixa umidade $(<40 \%)$ e descompactação, tais como o uso constante de ventiladores, aeração adequada, diminuição da lotação animal e adição de cama nova (seca).

Ao contrário do que tem sido especulado, a temperatura atingida na camada profunda da cama $\left(40\right.$ a $\left.50^{\circ} \mathrm{C}\right)$ não é suficiente para "pasteurizar" ou "esterilizar" a cama e, dessa forma, diminuir a população de bactérias causadoras de mastite. Dados de nosso estudo, realizado em propriedades no estado de São Paulo (monitoradas mensalmente por um ano), indicam que, devido à natureza orgânica da cama, esta sustenta uma população bacteriana muito maior do que a observada em camas inorgânicas como a de areia. No entanto, quando a cama é bem manejada e mantida 
seca e descompactada, as partículas não se aderem à pele dos animais, que permanecem em ótimas condições de conforto e higiene.

O monitoramento de alguns parâmetros de qualidade da cama, tais como a temperatura, umidade, compactação e escore de higiene dos animais (escores de sujidade do úbere, pernas e flanco), pode ser feito de forma prática em nível de campo e é fundamental para aprender a manejá-la e garantir sua estabilidade e qualidade.

Após um período de seis meses a um ano a cama pode ser substituída e vendida ou utilizada como fertilizante na própria propriedade. As propriedades agronômicas da cama "semi-compostada" ainda não estão esclarecidas e devem ser estudadas de forma científica para que essa possa ser aplicada de forma racional na agricultura. Ademais, embora o uso de madeira (serragem ou maravalha) tem sido o padrão para o sistema, diversos subprodutos agrícolas com disponibilidade regional, tais como a palha de trigo e a casca de café, têm potencial para uso, embora seja necessária validação científica.

Em nosso estudo, a maior dificuldade encontrada pelos produtores foi o controle da umidade e consequente compactação da cama. Como discutido anteriormente, camas úmidas e compactadas se tornam frias e mais aderentes, tornando os animais mais sujos e facilitando a transferência de patógenos para a pele dos tetos. As principais causas observadas do aumento de umidade e compactação da cama foram a entrada de chuva pelas laterais dos galpões, a falta de ventilação constante no galpão e a falta de aeração frequente e adequada.

Nossos resultados indicam que a mastite pose ser bem controlada se a cama for mantida em condições adequadas (seca e descompactada). Similarmente a outros sistemas de criação, tais como freestall e semi-confinamento, em nosso estudo os patógenos mais frequentemente isolados de casos de mastite clínica foram os coliformes, estafilococos coagulase-negativos e estreptococos ambientais. Não foram observados surtos de mastite ambiental durante o curso do estudo.

A umidade da cama foi o principal fator associado à incidência de mastite clínica ambiental. As chances de ocorrência de um caso de mastite clínica ambiental aumentaram 5,7\% para cada ponto percentual de aumento na umidade da cama. Ademais, a sujidade dos animais foi associada a um aumento das chances de mastite subclínica e a percentagem de vacas com mastite.

Em nosso estudo, as vacas permaneceram em excelentes condições de higiene quando alojadas no sistema de compostagem. Considerando escores de higiene animal variando de 1 (muito limpo) a 4 (muito sujo), as médias globais dos escores de úbere, teta, flanco e perna foram inferiores a 2,1 para todas as fazendas e não variaram entre as estações do ano. Um aumento da densidade (compactação) da cama foi associado a um aumento da sujidade dos animais e à concentração de bactérias totais no leite do tanque. Dessa forma, esses resultados sugerem que o manejo da cama visando mantê-la seca e descompactada resultará em animais mais limpos com menor risco de mastite.

Em conclusão, o sistema de compostagem possui potencial de implantação em condições brasileiras e poderia ser uma alternativa a sistemas ineficientes como o semi-confinamento, onde animais são alojados em condições inadequadas de conforto e higiene. Em futuro próximo, o sistema poderia ser incluído em programas de créditos de carbono e contribuir para a sustentabilidade da pecuária leiteira. No entanto, 0 entendimento dos princípios básicos do processo de compostagem e o manejo correto da cama são fundamentais para o sucesso do sistema. 


\section{Considerações gerais sobre os sistemas de produção em debate}

A produção de leite sobre cama de compostagem tem sido sistema bastante adotado no Rio Grande do Sul e sua viabilidade está diretamente ligada a um grande controle dos fatores de produção, alta capacidade de investimento (ou disposição para o endividamento) e alta capacidade técnica e gerencial. Comparado aos sistemas intensivos a campo, permite aumento da escala de produção de leite, redução dos problemas ambientais (erosão e barro) e aumento da renda. Por outro lado, sua viabilidade depende de hábil manejo nutricional e da cama, suprimento confiável e a preços justos em relação a insumos e matérias primas, além de certa estabilidade na remuneração do produto final (leite).

\section{Referências}

Barberg A.E., Endres M. I., Janni K.A. Compost dairy barns in Minnesota: A descriptive study. Applied Engineering in Agriculture 2007; 23(2): 231-238.

Black R.A., Taraba J.L., Day G.B., Damasceno F.A., Newman M.C., Akers K.A., Bewley J.M. The relationship between compost bedded pack performance, management, and bacterial counts. Journal of dairy Science 2014; 97(5): 2669-2679. https://doi.org/10.3168/jds.2013-6779.

Fávero S., Portilho F.V.R., Oliveira A.C.R., Langoni H., Pantoja J.C.F. Factors associated with mastitis epidemiologic indexes, animal hygiene, and bulk milk bacterial concentrations in dairy herds housed on compost bedding. Livestock Science 2015; 181: 220-230. http://dx.doi.org/10.1016/j.livsci.2015.09.002.

Favero S., Portilho F.V., Oliveira A.C., Langoni H., Pantoja J.C. Longitudinal trends and associations between compost bedding characteristics and bedding bacterial concentrations. Journal of Agricultural Science 2015; 7(10):58. http://dx.doi.org/10.5539/jas.v7n10p58.

Janni K.A., Endres M.I., Reneau J.K., Schoper W.W. Compost dairy barn layout and management recommendations. Applied Engineering in Agriculture 2007; 23(1): 97102. http://dx.doi.org/10.13031/2013.22333.

Kiehl E.J. Compostagem. In: Fertilizantes orgânicos. Agronômica Ceres, Piracicaba, São Paulo, Brazil. p. 229. 1985

\section{Autores}

Adriano Rudi Maixner ${ }^{1}$, Cristiano Kraemer Didoné ${ }^{2}$, José Carlos de Figueiredo Pantoja $^{3}$, Gilmar Roberto Meinerz ${ }^{4}$, Ricardo Lopes Machado ${ }^{5}$

1. Engenheiro Agrônomo e Professor da Universidade Federal de Santa Maria.

2. Produtor Rural.

3. Médico Veterinário e Professor do Departamento de Higiene Veterinária e Saúde Pública, UNESP-Botucatu.

4. Zootecnista e Professor da Universidade Federal da Fronteira Sul. Médico Veterinário e Extensionista Rural - Escritório Municipal da EMATER/RS Santa Maria. 